\title{
RESPONSES OF YOUNG DAIRY GOATS OFFERED NITROGEN SUPPLEMENT IN ISOCALORIC CONCENTRATE
}

\author{
A. Rai Somaning Asih ${ }^{1}$ dan B. A. Young ${ }^{2}$
}

\begin{abstract}
Sixteen growing female goats (Angora $\times$ Anglo-Nubiam) were assigned into a multiple latin square design experiment to evaluate the effectiveness of additions of different nitrogen (N) supplements to an isocaloric ration. In experiment I, nutrient intake and growth rate of 16 goats were assessed. In experiment 2, ration digestibility and $\mathrm{N}$ balance of 12 goats were assessed. The daily rations were $50 \%$ barley hay and $50 \%$ isocaloric concentrate. The given concentrate was either unsupplemented barley meal (BM), or BM supplemented with a nitrogen source. The $\mathrm{N}$ source may be soybean meal (BSBM), or Cottonseed meal (BCSM) or urea (BU) to provide 2.8 $\% \mathrm{~N}$ in the concentrate ration. The unsupplemented $\mathrm{BM}$ contained $1.7 \% \mathrm{~N}$. Addition of $\mathrm{N}$ to the ration did not affect growth rate, hay consumption or total metabolisable energy intake per $\mathrm{kg}^{0.75}$. although rotal DM and $N$ intake did increase $(\mathrm{P}<0.01)$. The addition of $N$ supplement without increasing energy in the diets, enhanced ration digestibility and $\mathrm{N}$ balance in goats but did not change $\mathrm{OM}$ or hemicellulose digestibility. There were no significant influences amongst the various nitrogen sources It can be concluded that when sufficient dietary energy is available for ruminal microbial activitics, the type of $\mathrm{N}$ source does not affect the rate of growth on young dairy goats, although the nutrient intake, nitrogen balance and ration digestibility may be increased
\end{abstract}

(Key words: Dairy goats, Nitrogen source, Energy; Growth and digestibility)

Buletin Peternakan 27 (2):55-62. 2003

\footnotetext{
'Fakultas Peternakan Universitas Mataram, Mataram.

${ }^{2}$ School of Animal Studies, The University of Queensland Gatton, QLD, 4345.
} 


\section{RESPON KAMBING PERAH TERHADAP SUPPLEMENTASI SUMBER NITROGEN YANG BERBEDA DALAM KONSENTRAT ISOKALORI}

\section{INTISARI}

Penelitian ini bertujuan untuk mengevaluasi respon penambahan sumber nitrogen $(\mathrm{N})$ yang berbeda dalam konsentrat isokalori terhadap kambing perah yang sedang tumbuh. Enam belas ekor kambing dialokasikan menurut rancangan Latin square berganda untuk meneliti konsumsi pakan dan pertumbuhan (Percobaan 1) dan 12 ekor dialokasikan untuk meneliti kecernaan pakan dan keseimbangan N (Percobaan 2). Ransum yang diberikan terdiri dari $50 \%$ barley hay dan $50 \%$ dari salah satu konsentrat: barley meal saja (BM); barley meal + bungkil kedele (BSBM); harley meal + bungkil kapas (BCSM) dan barley meal + urea (BU) Semua konsentrat mengandung 2,8 $\% \mathrm{~N}$, kecuali $\mathrm{BM}$ hanya mengandung $1,7 \% \mathrm{~N}$. Hasil penelitian menunjukkan bahwa penambahan $\mathrm{N}$ tidak mempengaruhi pertumbuhan, konsumsi hay dan konsumsi energi per $\mathrm{kg} 0,75$ bobot badan walaupun konsumsi DM dan $\mathrm{N}$ meningkat $(\mathrm{P}<0,01)$. Penambahan $\mathrm{N}$ tanpa meningkatkan energi ransum meningkatkan kecernaan dan keseimbangan $\mathrm{N}$, namun tidak mengubah kecernaan bahan organik dan hemiselulose dan tidak ada perbedaan pengaruh antara sumber $\mathrm{N}$. Sumber $\mathrm{N}$ tidak mempengaruhi pertumbuhan kambing perah walaupun konsumsi pakan, keseimbangan $\mathrm{N}$ dan kecernaan pakan meningkat, apabila ketersediaan energi mencukupi untuk aktivitas mikroba dalam rumen.

(Kata kunci Kambing perah, Sumber N, Energi, Pertumbuhan dan kecernaan).

\section{Introduction}

Growth rate and milk production of goats in developing countries are often low because the available feed resources are low in protein and energy content Traditionally, mature field grass and crop residues are used for goats, and Leng (1985) advocated such feed resources need protein supplementation to increase their nutritional value. However, conventional protein supplements (meat meal, fish meal, soybean and other legume grains) are very expensive in developing countries and animal use of high quality protein sources is in direct competition to use as a human food resources

Despite strong advocation for feeding of nitrogen supplements in review articles and books (Leng and Nolan, 1984, Leng, 1985; Crskov, 1992), not all studies have shown a conclusive benefit of feeding dietary nitrogen (N) supplements. Studies where different sources of nitrogen were offered to cattle (Galyean and Owens, 1991) and sheep (Milne et al. 1979) showed no significant responses in dry matter intake, digestibility of organic matter or neutral detergent fiber In vitro studies using ovine rumen microbes showed that microbial protein synthesis was not affected by added different nitrogen sources (Merry et al. 1990). Furthermore. Hadjipanayiotou (1992) reported that nitrogen supplements (untreated soybean; formaldehyde-treated soybean; fish meal) did not significantly affect growth rate in weaned female Damascus kid goats. There is some question as to the feeding value of added nitrogen supplements to isocaloric diets for ruminants, especially for goats, where there is limited research information.

The aim of the present study was to determine the effectiveness of different nitrogen supplements (barley meal plus soybean meal, cotton seed meal or urea) in isocaloric diets on total nutrient intakes, growth rate, diet digestibility and nitrogen balance in growing dairy goats. 


\section{Materials and Methods}

\section{Experiment 1. Growth rate and nutrient intake}

\section{Animals and diets}

Sixteen seven-month-old female crossbred (Angora $x$ Anglo-Nubian) with average initial body weight of $15 \pm 22 \mathrm{~kg}$ were penned in individual cages The goats were allowed an adjustment period of 4 weeks. during which time they were all fed the same diet of barley hay and concentrate which contained an equal mixture of three nitrogen sources (urea. cottonseed meal and soybean meal) used in the study $\ln$ addition. all goats were treated at the start of the study with hermectin to ensure freedom from intestinal parasites.

The animals were fed twice daily ration consisted of $50 \%$ hay and $50 \%$ concentrate and offered in equal amounts at 09:00 am and $17.00 \mathrm{pm}$ based on the amount of feed consumption during the preliminary sudies A mineral block was designed for goats (GoBlock. manufactured by Olsson Industries Pty Ltd Brisbane. Australia) and fresh water was also available ad-lib

Four isocaloric (3 Mcal ME/ky DM) concentrate supplements were used The control contained barley meal only (BM). The nitrogen supplemented concentrates were barley meal plus soybean meal (BSBM). barley meal plus cotton seed meal (BCSM) and barley meal plus urea (BU). Except for BM $(1.7 \% \quad N)$ al! diets were also isonitrogenous $(2.8 \% \mathrm{~N})$. The supplements were adjusted with small addition of canola oil and sucrose to achieve nominal $\mathrm{N}$ and energy content (Table 1).

\section{Design and experimental procedure}

A multiple latin square design (a $4 \times 4 \times 4$ rectangle), based on a design by Mead and Cumow (1983) was used in the growth rate trial The trial consisted of four periods of 5 weeks duration, including three weeks rest period to avoid carry-over effect from the previous treatment. During the rest period, the goats were offered the next-period diet and given two hours daily exercise in a small yard.

\section{Measurements}

Body weights were measured weekly immediately before the 9:00 feed. Daily feed intakes of both hay and concentrate were determined by subtracting any refusals from the amount offered DM and $\mathrm{N}$ intake of both hay and concentrate were calculated from laboratory analysis of daily feed offered and refusals, while ME intake relied on values from standard feed composition tables (NRC. 1981).

\section{Experiment 2. Digestibility study and nitrogen balance}

\section{Animals and diets}

Twelve fifteen-month-old female goats (the same goats as experiment 1) were used in experiment 2 . The weights of the goats were $29.7 \pm 3.1 \mathrm{~kg}$. All goats were $\mathrm{kept}$ in individual metabolic crates throughout the experimental period and a week was allowed for adjustment to the crates and feeds before starting measurements. During this adjustment period. all of the goats were fed the same concentrate diet containing barley meal and a mixture of the three nitrogen sources (urea. cottonseed and soybean meals) as in experiment 1

The same diets as in experiment 1 were evaluated and offered to animals at $90 \%$ of feed intakes as measured in experiment 1 The amount of concentrate and hay offered was calculated on the basis of $\mathrm{BW}^{0.75}$ to account for the heavier average body weight in experiment 2 The ratio of barley hay to concentrate offered was also based on the consumed ratio measured during the first experiment as follows: $34: 66$ (BM); 33:67 (BSBM); 31.69 (BCSM); and 32.68 (BU). As in experiment 1, the equal amount of feed was offered to the animals twice (09:00 and 17: $00)$. 


\section{Experimental procedure}

A Multiple latin square design (a $4 \times 4 \times j$ rectangle) was also used in the digestibility trial. The trial consisted of four treatment periods of three weeks duration. Digestibility and $\mathrm{N}$ balance measurement (total collection) were made during the last 5 days of each period.

In accord with the design of Mead and Curnow (1993), 3 animals randomly underwent one of the 4 treatments (BM, BSBM, BCSM, BU) in each period. No treatment was repeated in any animal, and each animal followed its own sequence, so that, at the end of the experiment all animals had completed all the 4 feeding treatments

\section{Sampling methods}

Total daily faecal output of each animal was measured and a 10 percent sub-samples collected every day and stored at $-16^{\circ} \mathrm{C}$. At the last day of the total collection in each period, the samples were pooled, thoroughly mixed and a 20 percent sub-sample dried in a forced draught oven at $60^{\circ} \mathrm{C}$ and then ground to I mm particle size prior to the chemical analysis Daily urine was collected into a plastic container containing glacial acetic acid $(50 \mathrm{ml})$ to trap nitrogen in the urine $\mathrm{A} 10$ percent sub-sample from each animal was frozen and stored at $-16^{\circ} \mathrm{C}$. These samples were pooled for each period and sub-samples taken for chemical analysis. The entire feed refusal for each animal was collected daily during the total collection and pooled for each period for later analysis.

\section{Chemical analysis}

The content of dry matter (DM), ash and organic matter (OM) of feeds, feed refusals and faeces samples were determined according to standard procedures (AOAC. 1984). The nitrogen contents were analyzed using an automatic FP-200 nitrogen analyzer (manufactured by LECO Corporation, Michigan, USA) based on the combustion method (Sweeney, 1989).

\section{Statistical analysis}

The data obtained was analyzed by using General Linear Model (GLM) procedure of $\mathrm{SAS}^{\varepsilon}$ (SAS Institute, Inc 1990). The differences between means were tested by using LSMEANS Test.

\section{Result and Discussion}

\section{Nutrient intake and growth rate}

The barley hay had $90.9 \%$ DM $114 \%$ N, $304 \%$ ADF, $621 \%$ NDF, $11.1 \%$ ash and $155 \mathrm{Mcal} \mathrm{ME} / \mathrm{kg}$. The chemical composition of the concentratc mixtures is shown in Table I. These concentrate mixtures were reasonably isoenergetic and isonitrogenous, except for the $\mathrm{BM}$ control

Table 1. Composition of concentrate (on "dry matter" basis)

\begin{tabular}{lccccccccc}
\hline Dicts & Bar M & SBM & CSM & Urea & Oil & Sugar & DM conc & N Conc. ME Conc. \\
& $(\%)$ & $(\%)$ & $(\%)$ & $(\%)$ & $(\%)$ & $(\%)$ & $(\%)$ & $(\%)$ & Mcal \\
\hline BM & 89.0 & 0 & 0 & 0 & 3.5 & 7.5 & 92.49 & 1.72 & 3.05 \\
BSBM & 83.5 & 16.5 & 0 & 0 & 0 & 0 & 91.74 & 2.82 & 2.91 \\
BCSM & 82.0 & 0 & 17.8 & 0 & 0.2 & 0 & 91.56 & 2.78 & 2.86 \\
BU & 86.3 & 0 & 0 & 2.5 & 3.5 & 7.7 & 92.38 & 2.81 & 2.87 \\
\hline
\end{tabular}

BM = Barley Meal, SBM = Soybean meal: $\mathrm{SM}=$ Cotton seed meal: Conc $=$ Concentrate 
Previous researchers have found that dietary protein supplements can increase the total dry matter intake of ruminants generally (Owens and Zinn, 1988; Milne et al., 1979), and in particular of goats (Mtenga and Kitaly, 1990). The present study also showed a significant increase in total DM intake induced by dietary nitrogen supplementation, but there was no significant difference in DM intake the various sources (Table 2).

The growth rates observed in the present study were $90.2,82.3,78,0,78.1 \mathrm{~g} /$ day for $\mathrm{BM} ; \mathrm{BSBM} ; \mathrm{BCSM}$ and $\mathrm{BU}$ diet tfeatment respectively. It is interesting to note that the control diet (BM), which had only $10.7 \% \mathrm{CP}$ in total ration, produced equivalent response in growth rate as the nitrogen supplemented diets which contained $18 \% \mathrm{CP}$. The relative high energy content of the diets used $(50 \%$ concentrate) and the association of readily available energy may have contributed to the similar growth performance of animals in all treatments, The concurrent release of readily available energy and ammonia was apparently producing optimum conditions for microbial growth in the rumen. This may have occurred in the BM control diet even though the N: ME ratio of this diet was significantly lower $(P<0.01)$ than the nitrogen supplemented diets (Table 2). The synchronized release of an available energy and ammonia may have been further enhanced by the combination of energy sources; barley hay (slow release), starch from barley meal (moderate release) and glucose from sugar (rapid release). Thus supporting the efficient conversion of ammonia to microbial protein. Furthermore, the concentrate had a moderate level of crude protein, which could have supplied sufficient peptide and amino acids for microbial growth (Beever, 1993).

The similar rate of growth in the BM control group compared with the supplemented $\mathrm{N}$ groups may be due to the similar ME intake (Table 2) and no statistically difference in the $\mathrm{OM}$ digestibility (Table 3). As the quantity of microbial crude protein synthesized in the rumen is closely correlated with digestible organic matter (DOM) intake, each $\mathrm{kg}$ DOM

Table 2 . Nutrient intake and weight gain of goats given different dietary nitrogen sóurces

\begin{tabular}{|c|c|c|c|c|c|}
\hline & \multicolumn{4}{|c|}{ Treatments } & \multirow[b]{2}{*}{$S E M^{\prime \prime}$} \\
\hline & $\mathrm{BM}$ & BSBM & $\mathrm{BCSM}$ & $\mathrm{BU}$ & \\
\hline \multicolumn{6}{|c|}{ Dry matter intake (/kg BW $\mathrm{BW}^{\mathrm{k} / 75}$ ) } \\
\hline Concentrate (g) & $38.9^{4}$ & $43.6^{h}$ & $44.6^{\mathrm{b}}$ & $41.8^{\mathrm{h}}$ & 0.8 \\
\hline Hay (g) & 22.5 & 23.3 & 22.6 & 21.8 & 1.11 \\
\hline Total DM (g) & $59.3^{\mathrm{a}}$ & $64.8^{b}$ & $65^{\circ}$ & $616^{\mathrm{nh}}$ & 1.4 \\
\hline Total OM (g) & $56.3^{\text {ah }}$ & $61.2^{a}$ & $620^{\mathrm{ac}}$ & $58.0^{\circ}$ & 1.23 \\
\hline \multicolumn{6}{|c|}{$\begin{array}{l}\text { Dietary nitrogen and energy intake } \\
\text { (kg BW }\end{array}$} \\
\hline Concentrate (g) & $0.66^{\mathrm{a}}$ & $1.28^{\prime \prime}$ & $1.27^{\mathrm{h}}$ & $1.22^{\mathrm{b}}$ & 002 \\
\hline Hay (g) & 0.26 & 0.26 & 0.26 & 0.25 & 0.01 \\
\hline Total Nitrogen (g) & $0.9^{\prime \prime}$ & $1.55^{\mathrm{b}}$ & $1.53^{\mathrm{b}}$ & $1.47^{\mathrm{b}}$ & 0.03 \\
\hline Total ME (Mcal) & $0.16^{\mathrm{a}}$ & $0.17^{\mathrm{a}}$ & $0.17^{\star A}$ & $0.17^{\mathrm{a}}$ & 0.004 \\
\hline Ratio N: ME (g/Mcal) & $5.72^{n}$ & $9.10^{b}$ & $9.04^{\mathrm{b}}$ & $8.87^{b}$ & 0.19 \\
\hline Average daily gain ( $\mathrm{g} /$ day) & 90.2 & 82.3 & 78.0 & 78.1 & 8.18 \\
\hline
\end{tabular}

Means within the same row with different superscripts are different **( $(\mathrm{P}<0,01)$.

$\mathrm{SEM}^{*}=$ standard error mean 
Table 3. Digestibility coefficient and nitrogen utilization by goats of isocaloric diets containing different nitrogen sources

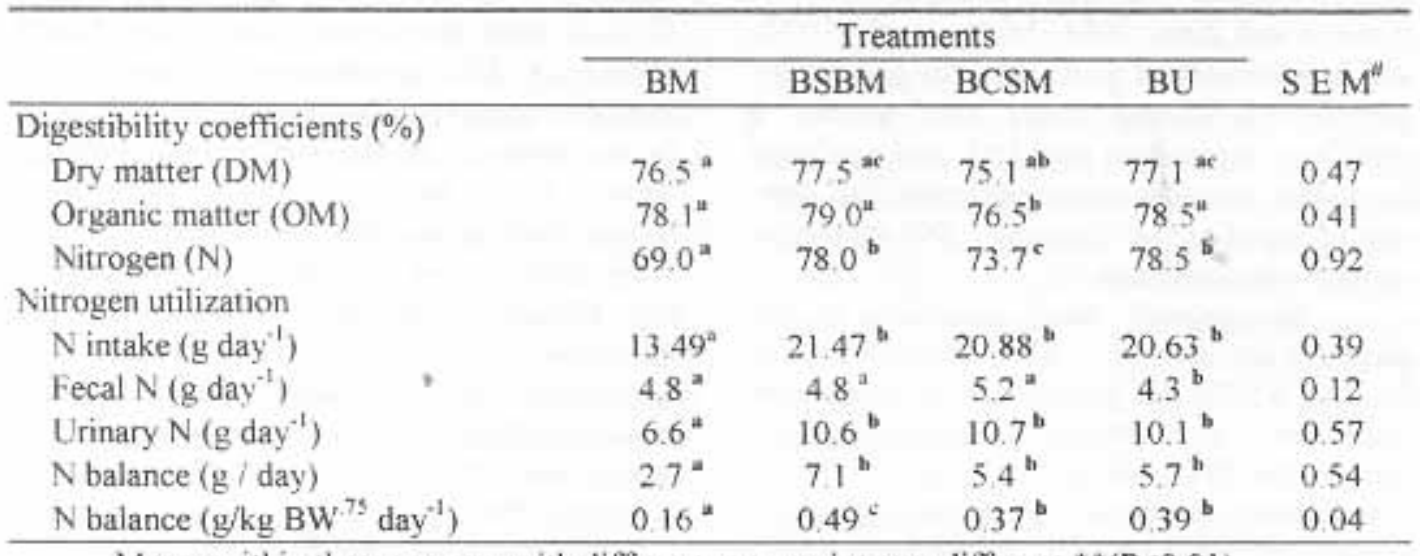

Means within the same row with different superscripts are different ${ }^{* *}(\mathrm{P}<001)$.

$\mathrm{SEM}^{ \pm}=$standard error mean.

can yield about $120-135 \mathrm{~g}$ microbial protein (Waldo and Glenn, 1984) Specifically for dairy goats, Laurent (1985) showed that microbial crude protein yield varied between 105 and $140 \mathrm{~g} / \mathrm{kg}$ DOM Thus the ME or DOM intakes may have had a greater role in growth rate than $\mathrm{N}$ intake or $\mathrm{N}$ retention. In the case of control animals, the amino acids generated from microbial protein may be sufficient to meet the amino acid requirements of the goats Moreover, Mtenga and Kitaly (1990) reported that the growth rate response of goats was mainly associated with increased dietary protein and energy intake. Thus there seems to be no benefit of adding dietary $N$ for goats when the dietary energy is sufficient.

The results of the present study are in agreement with those of Mtenga and Kitaly's work (1990). who found that there were no statistically $(\mathrm{P}>005)$ different responses in growth rate $(446,52.8 ; 62.5 \mathrm{~g} / \mathrm{d})$ amongst Tanzanian goats offered Chloris gayana hay supplemented with 200 g concentrates containing $10.2 ; 15.0$ and $17.7 \% \mathrm{CP} / \mathrm{kg} \mathrm{DM}$ respectively and about $2.4 \mathrm{Mcal} \mathrm{ME} / \mathrm{kg} \mathrm{DM}$. Daily gains of the goats in the present study were almost two-fold those reported by Mtenga and Kitaly's study (1990) although
DM intake per metabolic body weight was almost the same $\left(59.3-651 \mathrm{~g} /\right.$ day $W^{0.75}$ vs 55 $-77 \mathrm{~g} /$ day $\mathrm{W}^{075}$ ). This may be due to the higher energy content in the concentrates component of the diet.

The present study is also in agreement with Gregoire of al. (1996) who reported that there was little effect of protein supplements (soybean. soybean and protected methionine, herring meal and corn gluten meal) when diets were isocaloric $\left(3.7 \mathrm{Mcal} \mathrm{DE} \mathrm{kg}^{-1}\right)$ in relation to growth rate of Angora female goats.

\section{Digestibility study and nitrogen balance}

Other than $N$ digestibility. the $>$ supplemented diets did not differ constantly from the BM control in term of digestibility of diet component (Table 3). However, among the supplemented $\mathrm{N}$ groups, the cotton seed meal treatment had the lowest $(P<0.01) \mathrm{DM}$. $\mathrm{OM}$ and $\mathrm{N}$ digestibility (Table 3 ) While there were positive $\mathrm{N}$ balances across all treatments. the $\mathrm{BM}$ control was significant lower $(\mathrm{P}<001)$ compared to the nitrogen supplement treatments. Among the nitrogen supplement diets, the soybean treatment (BSBM) had a slightly higher $N$ balance, which reached 
statistically significance when expressed on a metabolic body size basis.

On cottonseed meal treatment (Table 3), the amount of nitrogen excreted in faeces and urine tended to be higher than other treatments, but not significantly different ( $P>0.05$ ). According to Van Straalen and Tamminga (1990), cottonseed meal has higher undegradable protein (UDP) than soybean meal ( $1.8 \%$ vs $0.1 \%)$, while the CP levels are not much different. This is in accord with AJ Jassim et al. (1991b), who reported that goats fed higher UDP diet excreted higher nitrogen in the faeces and urine $(P<0.01)$. The reduction in digestibility of DM, OM and $\mathrm{N}$ on cottonseed treatment, compared to soybean treatment, may be also related to the amount of UDP on the treament. According to Faichney (1971). who worked with lambs. UDP supplements (formaldehyde treated soybean meal) reduce nutrient digestibility $(\mathrm{DM}, \mathrm{OM}$ and $\mathrm{N}$ ) due to the higher outflow rate of digesta from the rumen

There were positive $\mathrm{N}$ balances across the treatments in the present study (Table 3). The control was significant lower ( $P<0.01)$ compared to the additional nitrogen treatments This difference in $\mathrm{N}$ balance was because of the significant lower $(P<0.01) \wedge$ intake Interestingly, with the urea treatment (BC). the $N$ balance was higher than those in soybean and cottonseed meal treatments. although the difference was not significant $(P>0.05)$. and the fecal $N$ excretion was significant lower $(\mathrm{P}<0.0])$ than for the cottonseed meal treatment (BCSM). That may mean that the NPN in the $B U$ diet was recycled back into the rumen.

\section{Conclusion}

There were no significant differences in growth rate, barley hay consumption and total metabolisable energy (ME) intake per kg metabolic body weight in growing dairy goats offered different dietary nitrogen sources. The addition of $\mathrm{N}$ supplement without increasing energy in the diets, enhanced digestibility and the balance of $\mathrm{N}$ in goats, but did not change OM or hemicellulose's digestibility. It can be concluded that when sufficient dietary energy is available for microbial activities, the source of $\mathrm{X}$ does not affect rate of growth in growing dairy goats, although the nutrient intake, nitrogen balance and digestibility may vary.

\section{Acknowledgements}

The authors are grateful to Kay Vockanson, A. L. Y Chen, Felix Gorbacz and Andy Goodwin for their skilled technical assistance, and Allan Lisle for statistical advice

\section{References}

Al Jassim, R. A. M, Al-Ani A N. Hassan S A and Dana T. K 1991 Effects of undegradable protein supplementation on digestion and nitrogen balance in sheep and goats. Small Rumi Res. 5. $57-63$

AOAC 1984. Methods of Analysis. 14th edn. Association of Official Analytical Chemists. Washington, DC 20044.

Beeset. D E 1993 Rumen Function. In: J. M Forbes and I France (Editors). Quantitative Aspects of Ruminant Digestion and Metabolism C. A B International. The University Press, Cambridge. UK pp 187-215

Faichney. G. J. 1971. The effect of formaldehyde-treated casein on the growth of ruminant lambs Aust. 1. Agric. Res., 22: 453-460

Galyean, M L and Owens F. N. 1991 . Effects of diet composition and level of feed intake in situ and extent of digestion in ruminants. In : T Tsuda, Y. Sasaki and R. Kawashima (Editors), Physiological Aspects of Digestion and Metaboiism in Ruminants Proceedings of the Seventh Intern. Symposium on Ruminant Physiology, Sendai, Japan Academic Press, lnc San Diego, California. pp. 483 - 514 . 
Gregoire, R. J., Fahmy M. H., Boucher J. M. Tremblay A. and Mercier J. 1996. Effect of four protein supplements on growth, feed conversion, mohair production, fibre characteristics and blood parameters of Angora goats. Small Rumin. Res, 19: 121-130

Hadjipanayiotou, M, 1992. Effect of protein source and formaldehyde treatment on lactation of Chios and Damascus goats Small Rumin Res . 8: (3). 185-197

Laurent, F. 1985. Flux d'acide ribonucleique dans le tube digestif de petits ruminants. (RNA flow in the digestive tract of small ruminants) These, Institute National Polytechnique de Lorraine, Nancy, France, 164 pp

Leng. R. A and Nolan J V., 1984, Nitrogen metabolism in the rumen. J. Dairy Sci., 67 (5) $1072-1089$

Leng. R. A 1985. Determining The Nutritive Value of Forage. In: G.J. Blair, D A lvory, T.R Evans (Editors). Forages in Southeast Asian and South Pacific Agriculture. Proceeding of an international workshop held at Cisaruat. Indonesia. 19-23 August. pp. 111-123.

Mead. R. and R. N. Cumow 1993. Statistical

Methods in Agriculture and

Experimental Biology. Chapman and Hall London. New York. 335 pp.

Milne. J. A., A. Christic and A. J. F Russel. 1979. The effects of nitrogen and energy supplementation on the voluntary intake and digestion of heather by sheep. J. Agric Sci., Camb. $92: 635-643$

Merry. R J. A. B McAllan and R H Smith 1990. In vitro continuous culture studies on the effect of nitrogen source on rumen microbial growth and fibre digestion. Anim. Feed Sci. Technol., $31: 55-64$.
Mtenga, L. A and A. J Kitaly. 1990. Growth Performance and Carcass Characteristics of Tanzanian Goats Fed Chloris gayana Hay with Different Levels of Protein Supplement. Small Ruminant Research, 3: 1-8.

NRC 1981. Nutrient Requirement of Domestic Animals, No. 15. Nutrient requirement of Goats Angora, Dairy. and Meat Goats in Temperate and Tropical Countries. National Academy Press, Washington DC, 91 pp

Orskov, E. R 1992. Protein Nutrition in Ruminants. $2^{\text {nd }}$ edn. Academic Press. London, New York. 175 pp.

Owens, F, N and R. Zinn 1988 Protein metabolism of ruminant animals. In

DC. Church (Editor), The ruminant animal, digestive physiology and nutrition. Prentice Hall, New Jersev pp. $227-249$

SAS Institute Inc 1990. SAS/STAT User's Guide, version 6, 4th edn. SAS Institute Inc. Cary. NC USA, Vol 2. pp 891 996

Sweeney R A 1989 Generic combustion method for determination of crude protein in feeds Collaborative study $\mathrm{J}$ Assoc Off Anal Chem., 72 (5) 770 774

Van Straalen, W. M. and S. Tamminga. 1990. Protein degradation of ruminant diets In: J Wiseman and D.J.A Cole (Editors). Feedstuff Evaluation Butterworths. Toronto pp 55-72

Waldo, D R and B P Glenn 1984 Comparison of new protein system for lactating cows I Dairy Sci. $67: 1115$ 1133 